Myšková, R., \& Hájek, P. (2019). Relationship between corporate social responsibility in corporate annual reports and financial performance of the US companies. Journal of International Studies, 12(1), 269-282. doi:10.14254/2071-8330.2019/12-1/18

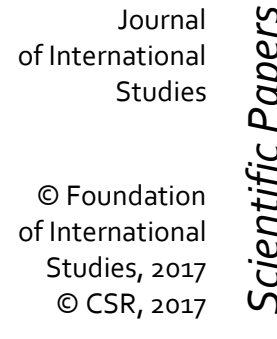

\title{
Relationship between corporate social responsibility in corporate annual reports and financial performance of the US companies
}

\author{
Renáta Myšková \\ Institute of Business Economics and Management, \\ Faculty of Economics and Administration, University of Pardubice, \\ Crech Republic \\ renata.myskova@upce.cz.

\section{Petr Hájek} \\ Institute of System Engineering and Informatics, \\ Faculty of Economics and Administration, University of Pardubice, \\ Czech Republic \\ petr.bajek@upce.cz.
}

Abstract. Achieving competitive advantage is becoming increasingly difficult in today's rapidly changing environment, and it is increasingly related to differentiation among competing companies. This concerns not only quality of products and economic results but also company's visibility as such. One way to present a responsible approach to entrepreneurship is via corporate social responsibility (CSR) - presenting this not only to company owners but also to other stakeholders, especially external ones. Potential investors can also be approached in this way. The total of 1380 listed US companies have been assessed as part of this research in 2014, both in terms of selected financial indicators and information they have published concerning their CSR activities. The aim was to find out which areas of CSR are presented by companies in their annual reports and whether a greater incidence of CSR information correlates with the selected financial indicators, which include company's market value and bankruptcy risk. For this purpose, a CSR dictionary was used. Four areas were evaluated: the environment, social community, human rights, and employee welfare. We demonstrate that companies with favorable financial performance show an emphasis on these areas. This finding has important implications for all stakeholders.

Keywords: corporate social responsibility, corporate annual report, financial ratio, topic analysis, dictionary, word list. 
JEL Classification: C34, G31, G33

\section{INTRODUCTION}

Not only is corporate social responsibility an important factor in allowing a company to present itself as friendly to the environment and own partners, but it also gives the company an opportunity to differentiate itself in competition and is, therefore, a potential source of competitive advantage. Forbes (2018) presents the statistics on the effect of CSR on consumer purchase decisions in the USA. In the 2016 survey, $32 \%$ of the respondents stated that CSR sometimes affected their decisions, while $16 \%$ said it had a strong influence on their purchasing decisions. Similarly, the survey of Deloitte (2018) shows that $77 \%$ of organizations considered CSR important and 18\% even treat it as top priority as reflected in their organizational strategies.

CSR, in simple terms, means a responsible business approach; if a company's workers and, primarily, its external stakeholders do not know of its CSR activities, this results in a company not utilizing a certain aspect of its non-financial potential. This, therefore, produces the need, or rather the necessity, to develop and simultaneously present their CSR activities as much as possible.

On the other hand, it is necessary to link the area of CSR to the area of economics in the sense of companies' financial results and the value of their assets. This means that it is necessary to find and evaluate the indicators with which company activities can be assessed from the financial perspective. Financial analysis, specifically ratio-based indicators, are used for this purpose. There are numerous studies focused on evaluating the relationships between CSR and select financial ratios; these are mentioned in the following section of this paper. Academic literature (Kim et al., 2012) also alleges that it is one thing to actually implement CSR activities and something very different to pretend they have been implemented. It is not possible to argue with this statement, though the goal of this paper is not to prove the truth of whether CSR activities have been conducted but to judge whether companies make information about CSR public and whether there is a relationship between the presence of information on CSR activities and the selected financial ratios. This approach is also unique in the sense that previous studies focusing on text analysis have focused almost exclusively on analyzing sentiment (Hajek et al., 2014; Myskova \& Hajek, 2016; Piryani et al., 2017; Myskova \& Hajek, 2017). From the published documents, it is possible to determine a whole range of other important information on companies' strategic focus as well as on their relationship to social responsibility - however, one that goes beyond positive and negative tone. Namely, stakeholders can perceive this type of company presentation more positively than the mere tone in the text (Pencle \& Malaescu, 2016). Therefore, in this study, we have focused on a company's annual report as the key document for transmitting management's communication to stakeholders. As part of the study, the total of 1380 American companies with stocks listed at stock exchange were evaluated from the perspective of the selected companies' financial ratios and the information they made public concerning their CSR activities. We have hypothesized that companies that present their CSR activities achieve better financial performance because CSR activities promote a sustainable business strategy (Cavaleri \& Shabana, 2018) and organizational change (Dobrovič \& Timková, 2017).

The remainder of this paper is structured as follows. In section 2, we provide a theoretical background on CSR and its relationship to financial performance. Section 3 introduces the research methods used in the study. In section 4, the empirical results are presented and discussed. Section 5 concludes the paper. 


\section{LITERATURE REVIEW}

\subsection{The Importance of CSR}

Corporate social responsibility (CSR) means voluntarily integrating social and ecological perspectives into a company's daily activities as well as into its interactions with stakeholders or interested parties. The principle consists of incorporating social and environmental perspectives into company strategy (including the primary focus of creating profit). Corporate social responsibility is linked with responsible business practice, sparing use of resources, and protecting the environment. It includes socially responsible behavior focusing on eliminating social problems (Huffman, 2013) as well as on social initiatives and philanthropic activity (Labuschagne \& Brent, 2008; Engert \& Baumgartner, 2015).

Van Marrewijk (2003) describes CSR by primarily focusing on companies and their environment. Companies that apply corporate social responsibility in a responsible way are able to achieve better results from business activities, because socially responsible behavior leads to eliminating social problems (Huffman, 2013), develops the abilities to effectively utilize all company resources, and thus provides an advantage over the competition (Torugsa \& O'Donohue, 2012). Social initiatives and philanthropic activity are also realized as part of CSR (Labuschagne \& Brent, 2008).

Primarily, the reasons for implementing CSR can be seen in outperforming the competition, strengthening company reputation and credibility (Archel et al., 2011; Contrafatto, 2014), the necessity of paying attention to the environment and respecting the relevant norms on environmental protection. Schreck (2011) makes a connection between CSR activity and improving company competitiveness. It is possible to develop a competitive advantage by engaging in a number of environmentally focused activities (Porter \& Van der Linde, 1995; Sarkis, 2009; Rajnoha \& Lesníková, 2016), including creating ecological supply chains (Wolf, 2014; Agan et al., 2016). External pressure for institutionalizing sustainability is also reflected in the area of CSR, but because more and more companies are engaging in CSR activities, the benefits of implementing relating activities are decreasing (Flammer, 2013). Again, all this emphasizes the need to present CSR activities and focus on obtaining advantages that are perhaps not measurable in the present but may be seen only in the future.

\subsection{Interconnection Between the Corporate Financial Perspective and CSR Activities}

Lagoarde-Segot (2018) states that the financial system is meant to ensure that income is spent properly (consumption) on the basis of liquidity; to make sure that capital is used on suitable investments, including the use of loans; and also to create suitable conditions for dealing with unpredictable events that exist between the need for liquidity and the need for credit. According to this author, developing financial knowledge should, however, start with acknowledging diversity in methods of coordination and the methods by which the environment and institutions model the skills that participants use to enter into contact with third parties. It is thus clear that financial management is also closely linked with other company activities, including CSR activities. Another important area where it is necessary to accept the interconnection of a company's financial perspective with its achievement of excellence and sustainability is strategic management and strategy creation, primarily business strategy (Cavaleri \& Shabana, 2018). It has been shown that the process of planning changes, checking upon changes, and the time needed to implement changes have an important role and a major effect on the ultimate success or failure of change in a company (Dobrovič \& Timková, 2017).

The relationship between implementing CSR and achieving financial results has been examined in a number of academic studies, often on the basis of evaluating ratio-based financial indicators. However, 
the results of academic studies are not clear-cut, which is pointed out in Javed et al. (2016) and Seele and Gatti, (2015).

A positive relationship between CSR activities and financial performance has been described by Weber (2008), Wagner (2010), and Di Segni et al. (2015), for example. Reverte et al., (2016) have described CSR's positive influence on financial results.

Financial ratios dealing with profitability, primarily ROA and ROE, are used frequently to evaluate CSR's influence (Kimmel et al., 2013). Turban and Greening (1996) found a positive relationship between CSR and ROA for large companies; Galbreath (2006) similarly alleged in a study on Australian companies that CSR is positively linked to financial results as measured by both ROA and return on equity (ROE). On the other hand, Cowen et al. (1987) described a negative relationship between CSR and ROE; similarly, Friedman (1970) and Becchetti and Ciciretti (2009) describe a negative relationship between CSR and corporate financial performance. According to Crisóstomo (2011), there are positive, negative, and neutral arguments relating to the relationship between CSR and companies' financial performance. At the same time, there are also studies alleging that CSR has an insignificant influence on business performance (Surroca et al. 2010).

Simionescu (2016) indicated that most of the variation in financial performance is explained by the book-to-market ratio and the cash-to-assets ratio. Bayaraa (2017) states that ROA has more determinants than ROE and ROS, such as earnings per share, and that return on costs has a positive impact.

Brammer et al. (2006) also conducted research focused on the relationship of CSR and company market value and came to the conclusion that there is an inverse (negative) relationship between CSR and market value.

It is also important to take into consideration that the consumption of a certain amount of resources is connected to CSR. However, according to Engert and Baumartner (2015), certain companies may not be able or willing to invest in this area.

\section{METHODOLOGY}

For the study, we selected 1380 companies along with their annual reports for 2014. These companies were subjected to both financial analyses as well as to an analysis of word occurrence in relation to ratio values. The reason for using data from 2014 is the fact that a paid database was used; it was acquired as part of the project and provides a comprehensive group of companies, which means that there is no problem with the sample being representative. As noted by Myskova \& Hajek (2017), investor sentiment has been more optimistic since 2013, as compared with previous years. This is explained by the growth of major U.S. stock exchanges. Importantly, this trend is reported to remain to the present day.

The following research questions were the starting point for conducting the study.

1. Is there a correlation between information on CSR and the selected ratios?

2. How do the companies being examined present information about CSR in relationship to the values that were achieved for the selected financial ratios?

3. Do the companies that provide more information about CSR have higher average market and book values?

4. Overall, is there a correlation between information about CSR and the companies' overall financial performance?

To evaluate the companies' approach to CSR, we used a recently developed CSR dictionary (Pencle \& Malaescu, 2016). This dictionary covers four CSR topics: (1) employees (human resources, 319 words); (2) society and community (174 words); (3) the environment (451 words); and human rights (297 words). 
This dictionary is available at https://provalisresearch.com/Download/CSR.zip. In the study by Pencle and Malaescu (2016), it was demonstrated that this dictionary can be used effectively to evaluate a firm's attitude to CSR by using IPO prospectuses as the source of textual data. Here, we used the dictionary to study attitudes to CSR based on the text comments provided by managers in their annual reports. These texts are suitable for such analysis because they include discussion on business strategy, recent events, labor issues, social and environmental risks, etc.

The annual reports (10-K forms) of 1380 US companies were drawn from the database of the U.S. Securities and Exchange Commission (SEC; www.sec.gov). As in previous research (Engelberg et al., 2012; Hajek \& Henriques, 2017), we calculated the raw frequency of the words in each word category (topic) and divided these frequencies by the overall number of words in the annual reports. Thus, relative frequencies that take the length of the annual reports into consideration were obtained. Only companies listed on the Nasdaq or New York Stock Exchange (NYSE) were included, with average market capitalization of 10,862 mil. USD. This is, the companies were highly liquid and had a high market capitalization. Given the strong dependency of financial indicators on industry category, only nonfinancial companies were included, with the majority of companies categorized in manufacturing industry.

A more detailed description of the types of activities examined can be presented as follows: a focus on eliminating corruption; transparency; good relationships and communication with customers, stockholders, and commercial partners; respecting intellectual property rights; strict adherence to human rights; maintaining work standards; and philanthropy. From the environmental perspective, examples of the issues examined include ecological certification, ecological politics, recycling, and conservation of the natural resources being used.

When selecting financial ratios, it was taken into account that academic literature and the studies presented did not clearly indicate a preferred ratio for assessing CSR benefits from the financial perspective. Therefore, the ratios that are used for studying and evaluating the selected companies cover the areas of debt (the book debt-to-capital ratio), profitability (ROA, ROE, and ROS), activity (the asset turnover ratio), solvency (NWC/TA), and market value.

The book debt-to-capital ratio - the ratio of debt to the company's capital - essentially expresses the willingness to finance the company's activities with external capital, which is prioritized over its own resources as a source of financing. This thus specifies the level of risk for stockholders. It is considered a test of financial standing and a measure of creditworthiness; it also makes it possible to judge whether a company can meet its obligations. It generally holds that the higher this ratio, the higher the risk for stockholders and creditors, though it is always necessary to make allowances for the actual industry, the company's life phase, and other specific aspects. Nonetheless, companies with a higher level of debt will need a stable flow of money; therefore, a ratio value of 0.6 was selected as the threshold value.

Return on equity (ROE) is a commonly used profitability ratio. It was selected as an indicator of how much equity is being increased using earnings after taxes. Because the companies are not active in just one sector, it is not possible to judge ROE in regards to the sector, but we can start with the fact that this value should equal more than $12 \%$ in stable economies (Komanshie, 2014). This ratio was monitored because it measures the effectiveness with which a company uses the owners' capital - it clearly expresses how much net profit is generated per CZK of the capital invested by stockholders. However, a higher ROE value does not necessarily mean better financial performance for a company, because it could be the result of a strong financial leverage effect, and having too much financial leverage is dangerous for solvency. Nonetheless, the equity's profitability should always be higher than the possible yield of an investment with the same risk or, for example, the average yearly return on five-year state bonds to maturity. 
The next ratio that was examined - ROS, i.e., return on sales - measures the share of net profit generated per CZK of sales. It was included because a large percent of stakeholders consider market growth an essential measure of company success, even though it is always only possible to evaluate this ratio in a relative context. This is because a low value for this ratio if it occurs along with a fast turnover of goods and a high total sales volume, can be more favorable than a high value accompanied by a slow turnover of goods and low total sales. For a more precise interpretation of the ratio, it is necessary to either know a given company's long-term prospects for its developmental trend and the value of the relevant sector or to judge it in conjunction with other ratios. Therefore, the total assets turnover ratio has been selected as the other indicator; this is the ratio of turnover to overall assets and assesses how effectively an organization's overall assets are being used. Its value should be higher than 1 for one accounting period (1 year).

Total Assets Turnover (S/TA) represents the effectiveness of the use of total assets, indicating how effectively assets are deployed in generating revenue. If the value of the indicator fluctuates below the industry average, revenue-generating activities should be strengthened, or it is necessary to reduce the investment or to sell some assets.

Net working capital (NWC) represents the resources able to be used to cover expenses in the event of an unexpected negative occurrence (Sedláček, 2011). NWC is considered an indicator of short-term liquidity, expressing how much of the operating assets will be available to the company when it meets all its short-term liabilities. A principle of financial management suggests that it is necessary to cover shortterm assets with short-term liabilities, as there is no increase in the cost of securing short-term assets. NWC therefore indicates the value of short-term assets covered by long-term liabilities. It can also be said that it represents resources that generate company's revenue. For evaluating this, the percentage of net working capital to assets is used (NWC/TA), which expresses the amount of NWC contained in the assets. For manufacturing companies, the ratio should show values in the range of $10-15 \%$.

The last ratio that was selected is price book value (PBV); it measures stock's market price to book price. If its value is greater than 1, the company's market value is greater than the book value of its equity, which represents a company's sufficient potential ability for asset reproduction value regarding the amount of business risk and the volume of share capital. The data's basic descriptive statistics are listed in Table 1. In addition to the above-mentioned financial ratios, we also included the $Z$-score indicator of overall financial performance, as described in the following section.

Table 1

Descriptive Statistics for the Financial Ratios and CSR Areas

\begin{tabular}{|l|c|c|c|}
\hline Category & Variable & Mean & St.Dev. \\
\hline Profitability & ROE & 0.152 & 2.108 \\
& ROS & 0.057 & 0.491 \\
\hline Activity & S/TA & 0.842 & 11.240 \\
\hline Market & PBV & 6.505 & 54.558 \\
Liquidity & NWC/TA & 0.281 & 3.840 \\
\hline Leverage & BD/TA & 0.482 & 0.202 \\
\hline Overall financial performance & Z-score & 2.670 & 3.896 \\
\hline CSR areas & employee & 0.0216 & 0.0049 \\
& environment & 0.0350 & 0.0062 \\
& human rights & 0.0191 & 0.0037 \\
& social community & 0.0216 & 0.0043 \\
\hline
\end{tabular}

Source: Authors' results. $\mathrm{ROE}=$ return on equity, $\mathrm{S}=$ sales, $\mathrm{TA}=$ total assets, $\mathrm{PBV}=$ market price to book value, $\mathrm{CF}=$ cash flow, $\mathrm{NWC}=$ net working capital, and $\mathrm{BD}=$ book debt. 


\section{EMPIRICAL RESULTS AND DISCUSSION}

First, we investigated whether there is a significant difference between the attitudes to individual categories of CSR and financial performance. Student's paired $t$-tests were used for this purpose. Individual correlations were judged from the perspective of the values achieved for individual financial ratios, with the companies under investigation divided into two groups using the threshold values of the respective ratio (found in the previous text). For the indicators that were able to have a set value, this value was established using the values recommended in the scientific literature.

The difference between the specified groups of companies is clearly seen in Table 2, with companies having higher debt showing less occurrence of words referring to CSR in the text. Concerning CSR activity categories, the area of the environment is focused on the most, with social and employee activities following next. The order of importance for the areas observed is consistent with that of the companies having debt under the threshold value of 0.6.

Table 2

Comparing CSR Vocabulary to Financial Performance Using BD/TC

\begin{tabular}{|l|c|c|c|l|}
\hline & \multicolumn{4}{|c|}{ BD/TC (Book debt to capital ratio) } \\
\hline Vocabulary & average for $\leq 0.6$ & average for $>0.6$ & $t$-statistics & \multicolumn{1}{c|}{$p$-value } \\
\hline employee & 0.0217 & 0.0212 & 1.658 & $0.098^{*}$ \\
\hline environment & 0.0353 & 0.0342 & 2.730 & $0.006^{* * *}$ \\
\hline human rights & 0.0191 & 0.0192 & -0.533 & 0.594 \\
\hline social community & 0.0218 & 0.0213 & 1.884 & $0.060^{*}$ \\
\hline
\end{tabular}

Source: Authors' results. * significantly different at $p<0.1, * *$ at $p<0.05$, and $* * *$ at $p<0.01$

Table 3 lists the correlation values in connection with the ROE value. Here, it is again true that the group of companies with a higher return on equity tend to present CSR activities more frequently. Concerning the CSR activity categories, the area of the environment is again emphasized, with the employee and social activities next. The significance of activities aimed at the environment is also clear for companies with lower ROE; the social and employee areas follow in importance.

Table 3

Comparing CSR Vocabulary to Financial Performance Using ROE

\begin{tabular}{|l|c|c|c|l|}
\hline & \multicolumn{3}{|c|}{ ROE } & \multicolumn{3}{|c|}{-statistics } & $p$-value \\
\hline Vocabulary & average for $>12 \%$ & average for $\leq 12^{\%} \%$ & 3.000 & $0.003^{* * *}$ \\
\hline employee & 0.0221 & 0.0213 & 1.204 & 0.229 \\
\hline environment & 0.0353 & 0.0348 & 2.318 & $0.021^{* *}$ \\
\hline human rights & 0.0194 & 0.0189 & 2.098 & $0.036^{* *}$ \\
\hline social community & 0.0219 & 0.0214 & \\
\hline
\end{tabular}

Source: Authors' results. * significantly different at $p<0.1, * *$ at $p<0.05$, and $* * *$ at $p<0.01$

The ROS ratio was evaluated only as it concerned an increasing value; namely, it was not possible to establish the threshold value. Therefore, we investigated only significant correlations between the attitudes to individual CSR categories and ROS. Spearman correlation coefficients were used for this purpose. Significant correlations at a level of $p<0.05$ were obtained for two areas of CSR, i.e., the environment and social community (Table 4). 
Comparing CSR Vocabulary to Financial Performance Using ROS and Correlation Coefficients

\begin{tabular}{|l|c|}
\hline Vocabulary & ROS \\
\hline employee & 0.032 \\
\hline environment & $0.210^{*}$ \\
\hline human rights & 0.029 \\
\hline social community & $0.148^{*}$ \\
\hline
\end{tabular}

Source: Authors' results. * significant correlation at $p<0.05$

The positive correlation between presenting CSR activities and S/TA shows the highest values for the area of the environment (Table 5). Industry average for U.S. non-financial companies was 0.758 in 2014 (U.S. Census Bureau, 2015). Here we used 1 as the threshold value because the recommended values for manufacturing companies are in the range 1-1.5.

Table 5

Comparing CSR Vocabulary to Financial Performance Using S/TA

\begin{tabular}{|l|c|c|c|c|}
\hline & \multicolumn{4}{|c|}{ S/TA } \\
\hline Vocabulary & average for $>1$ & average for $\leq 1$ & $t$-statistics & $p$-value \\
\hline employee & 0.0225 & 0.0212 & 4.748 & $0.000^{* * *}$ \\
\hline environment & 0.0348 & 0.0354 & 1.573 & 0.116 \\
\hline human rights & 0.0196 & 0.0189 & 3.647 & $0.000^{* * *}$ \\
\hline social community & 0.0220 & 0.0214 & 2.458 & $0.014^{* *}$ \\
\hline
\end{tabular}

Source: Authors' results. * significantly different at $p<0.1, * *$ at $p<0.05$, and $* * *$ at $p<0.01$

If companies achieved a greater share of NWC/TA, they then focused more on CSR - again, with emphasis on the environment. However, activities are also evident in the social and employee areas. For companies with a lower NWC/TA value, the situation is similar concerning priority, though the order of social activities and employee activities is reversed (Table 6). NWC/TA in the range of 10-15\% reflects a relatively large volume of funds tied to long-term assets (buildings and machines) in non-financial companies. The threshold selected for NWC/TA takes into consideration that if manufacturing companies keep less than 15\% of NWC in proportion to its TA, their operation is endangered. The average NWC/TA ratio for U.S. industrial companies is around 12\% (Petř́k, 2005).

Table 6

Comparing CSR Vocabulary to Financial Performance Using NWC/TA

\begin{tabular}{|l|c|c|c|l|}
\hline & \multicolumn{4}{|c|}{ NWC/TA } \\
\hline Vocabulary & average for $>0.15$ & average for $\leq 0.15$ & $t$-statistics & $p$-value \\
\hline employee & 0.0219 & 0.0210 & 2.968 & $0.003^{* * *}$ \\
\hline environment & 0.0357 & 0.0331 & 7.059 & $0.000^{* * *}$ \\
\hline human rights & 0.0192 & 0.0188 & 2.130 & $0.033^{* *}$ \\
\hline social community & 0.0220 & 0.0207 & 4.978 & $0.000^{* * *}$ \\
\hline
\end{tabular}

Source: Authors' results. * significantly different at $p<0.1, * *$ at $p<0.05$, and $* * *$ at $p<0.01$

From Table 7, it is clear that companies whose market value is greater than their book value present CSR activity more often than companies with a PBV less than 1. In both groups, there is still a clear emphasis on environmental activity. 
Comparing CSR Vocabulary to Financial Performance Using PBV

\begin{tabular}{|l|c|c|c|l|}
\hline & \multicolumn{4}{|c|}{ PBV } \\
\hline Vocabulary & average for $>1$ & average for $\leq 1$ & $t$-statistics & $p$-value \\
\hline employee & 0.0218 & 0.0207 & 2.654 & $0.008^{* * *}$ \\
\hline environment & 0.0353 & 0.0333 & 4.072 & $0.000^{* * *}$ \\
\hline human rights & 0.0192 & 0.0186 & 1.892 & $0.059^{*}$ \\
\hline social community & 0.0219 & 0.0202 & 4.841 & $0.000^{* * *}$ \\
\hline
\end{tabular}

Source: Authors' results. * significantly different at $p<0.1, * *$ at $p<0.05$, and $* * *$ at $p<0.01$

From all the comparisons conducted, it can be seen that the area of human rights is described the least, which is most likely linked to the fact that this is an area handled by legislation, and violating human rights is closely watched not only by government institutions but also by other stakeholders. Therefore, company management considers activity in this area more or less obvious and highlights only specific information from this area.

The answer to the question of whether there is a correlation between information on CSR activities and the selected financial ratios is affirmative. If we simplified the financial analysis explanation so that we consider higher values to be positive for all ratios, with the exception of book debt-to-capital, we can also then comment on the correlations between values of the monitored ratios and the occurrence of information concerning CSR activities.

Considering the degree of debt and its possible increase as a result of expenses on CSR activity, the results correspond to the fact that companies with high debt implement CSR activities in a limited way; therefore, they can also only present them in a limited way.

Conversely, other ratios - primarily profitability ratios - show a positive correlation in all the areas examined, and a more detailed presentation of CSR activities is clearly linked to an increasing value for the S/TA ratio. High sales enable companies to develop their CSR, with this also appearing in annual report commentary.

Networking capital to overall assets often tends to be judged only from the financial perspective and from the viewpoint of eliminating possible risk; therefore, management supports maximizing this and understands that working capital generates company value. A result of developing CSR activities is that CSR helps to limit the occurrence of certain risks, which actually has an additional positive influence on the amount of net working capital. The positive correlation between both variables corresponds to this.

There is a clear significant positive correlation between PBV and the number of comments about CSR for all the areas examined. From this, it can be deduced that management at successful companies with a growing market value is aware of the necessity not only of developing CSR but also of presenting their activities.

We applied the Altman Z-score model to evaluate the companies' overall financial performance. This model is predominantly used to assess the financial health of US companies. More precisely, we used the version of the model specifically developed for US public manufacturing companies. Therefore, this model conforms to the companies assessed in this study. In fact, this model works as a predictor of financial distress. Thus, a higher $Z$-score also denotes a higher probability of survival over the next several years (the accuracy of this model is reported to be high - up to three years in advance). The Altman $Z$ score model can be calculated using the following equation:

$Z=1.2 x_{1}+1.4 x_{2}+3.3 x_{3}+0.6 x_{4}+1.0 x_{5}$, 
where $x_{1}$ denotes working capital/total assets, $x_{2}$ represents retained earnings/total assets, $x_{3}$ is earnings before interest and tax/total assets, $x_{4}$ denotes the book value of equities/book value of total liabilities, and $x_{5}$ represents sales/total assets. The following categorization is recommended for the $Z$-score value: if $Z \geq 3.00$, the company is in the "safe zone" (a financially strong company); if $1.80 \leq Z \leq 2.99$, this indicates the "gray zone" (a company with certain financial difficulties); and if $Z<1.80$, it is in the "distress zone" (serious financial problems, endangered by bankruptcy). After calculating the Z-score values, the companies in our dataset were classified into the following categories: $29.8 \%$ in the "safe zone," $38.8 \%$ in the "gray zone," $27.5 \%$ in the "distress zone," and at least one ratio in Eq. (1) was missing for 3.9\%. The $Z$-score categories are compared in Table 8 in terms of CSR variables.

Table 8

Comparing CSR Vocabulary to Financial Performance Using the Z-score

\begin{tabular}{|c|c|c|c|c|}
\hline & \multicolumn{4}{|c|}{ Z-score } \\
\hline Vocabulary & $\begin{array}{l}\text { average for } \\
\text { „safe zone“ }\end{array}$ & $\begin{array}{l}\text { average for } \\
\text { „grey zone“ }\end{array}$ & $t$-statistics & $p$-value \\
\hline employee & 0.0227 & 0.0217 & 2.911 & $0.004^{* * *}$ \\
\hline environment & 0.0355 & 0.0356 & -0.224 & 0.823 \\
\hline human rights & 0.0197 & 0.0190 & 3.014 & $0.003^{* * *}$ \\
\hline \multirow[t]{2}{*}{ social community } & 0.0221 & 0.0218 & 1.368 & 0.172 \\
\hline & $\begin{array}{l}\text { average for } \\
\text { „grey zone“ }\end{array}$ & $\begin{array}{c}\text { average for } \\
\text { „distress zone“ }\end{array}$ & $t$-statistics & $p$-value \\
\hline employee & 0.0217 & 0.0204 & 4.316 & $0.000 * * *$ \\
\hline environment & 0.0356 & 0.0340 & 3.523 & $0.000^{* * *}$ \\
\hline human rights & 0.0190 & 0.0185 & 2.151 & $0.032 * *$ \\
\hline \multirow[t]{2}{*}{ social community } & 0.0218 & 0.0210 & 2.572 & $0.010^{* *}$ \\
\hline & $\begin{array}{l}\text { average for } \\
\text { „safe zone“ }\end{array}$ & $\begin{array}{c}\text { average for } \\
\text { „distress zone“ }\end{array}$ & $t$-statistics & $p$-value \\
\hline employee & 0.0227 & 0.0204 & 6.172 & $0.000 * * *$ \\
\hline environment & 0.0355 & 0.0340 & 3.248 & $0.001 * * *$ \\
\hline human rights & 0.0197 & 0.0185 & 4.462 & $0.000^{* * *}$ \\
\hline social community & 0.0221 & 0.0210 & 3.431 & $0.001 * * *$ \\
\hline
\end{tabular}

Source: Authors' results. * significantly different at $p<0.1, * *$ at $p<0.05$, and $* * *$ at $p<0.01$

The results show that companies in the "distress zone" have significantly lower frequencies of CSR terms in their annual reports when compared with the "gray zone" and a "safe zone," respectively. This suggests that companies focusing on CSR have a significantly lower probability of bankruptcy than the remaining companies. This also conforms to our previous results and clearly demonstrates the positive relationship between a focus on CSR activities and corporate financial performance.

Finally, the effect of CSR vocabulary on $Z$-score values was investigated. A general linear model was employed for this task, including the context of the annual reports' concepts as control variables. The concepts represent the main topics of the annual reports under investigation. To find the concept values, we used latent dirichlet allocation (LDA) (Blei et al., 2003), a generative probabilistic model for detecting a mixture of hidden topics. The experiment was performed in the Stanford Topic Modeling Toolbox 0.4.0. First, text pre-processing was conducted, including tokenization, conversion of tokens to lower case letters and stop words removal. To determine the number of concepts, we used perplexity indicator, which represents the number of equiprobable word choices on unseen data. Using a rule of thumb, we selected six concepts for which the perplexity started to decrease. Using the words with largest weights, we were able to label those concepts as follows: (1) corporate restructuring, (2) investment policy, (3) technology, (4) foreign market, (5) financial policy and (6) accounting principles. These were used to model the context of CSR vocabulary in the general linear model. Another problem to be addressed was 
multicollinearity. Using the variance inflation factor, we detected strong correlations among CSR topics. More precisely, employee, human rights and social community topics exhibited strong correlations. Therefore, factor analysis based on maximum likelihood estimates was used to obtain a factor (called CSR - social) representing the three intercorrelated variables. Other standard tests were performed to avoid heteroscedasticity (the Levene's test), non-normality of unstandardized residuals (the Shapiro-Wilk test) and first order linear auto-correlation (the Durbin-Watson statistics).

The results of the general linear model are presented in Table 9. The value of R2 suggest that we were able to explain about $22 \%$ of the variance in $Z$-score using the CSR vocabularies and annual reports' concepts. CSR - environment topic was not a significant determinant, whereas CSR - social had significantly positive effect on the $Z$-score values. This corroborates our previous findings based on the results in Table 8. Other significantly positive determinants included investment policy and foreign market. In contrast, corporate restructuring and financial policy topics indicated a decrease in the $Z$-score values.

Table 9

Effect of CSR Vocabulary on Z-score in the Context of Annual Reports' Concepts

\begin{tabular}{|l|c|c|c|l|}
\hline & coef. $b$ & std. $b$ & $t$-statistics & \multicolumn{1}{|c|}{$p$-value } \\
\hline intercept & 1.546 & 0.482 & 3.206 & $0.001^{* * *}$ \\
\hline CSR - environment & -5.244 & 9.676 & -0.542 & 0.588 \\
\hline CSR - social & 79.442 & 14.553 & 5.459 & $0.000^{* * *}$ \\
\hline corp. restructuring & -19.923 & 10.351 & -1.925 & $0.054^{*}$ \\
\hline invest. policy & 22.905 & 1.922 & 11.917 & $0.000^{* * *}$ \\
\hline technology & -2.415 & 1.916 & -1.261 & 0.208 \\
\hline foreign market & 19.100 & 2.015 & 9.479 & $0.000^{* * *}$ \\
\hline financial policy & -9.058 & 1.862 & -4.864 & $0.000^{* * *}$ \\
\hline accounting principles & -0.738 & 1.832 & -0.403 & 0.687 \\
\hline $\mathrm{R}^{2}$ & 0.223 & & & \\
\hline $\mathrm{R}^{2}-$ adj. & 0.219 & & & \\
\hline$N$ & 1380 & & & \\
\hline
\end{tabular}

Source: Authors' results. ${ }^{*}$ significant at $p<0.1,{ }^{* *}$ at $p<0.05$, and $* * *$ at $p<0.01$

\section{CONCLUSION}

Comments on CSR activities are presented in the annual reports of the companies under examination, and the analysis results show that there is a correlation between financial results assessed according to the selected ratios from financial analysis and the number of information companies present concerning CSR. Worse financial results are linked to less information on CSR. An inverse relationship was confirmed for debt and information on CSR activities. However, from the financial perspective, it is appropriate to add that a company having greater debt does not necessarily present a problem. Conversely, it is possible to increase the overall profitability of a company's equity by increasing its debt. This relationship can positively influence a company's market value. On the other hand, it impossible to overlook the risk linked to financial instability. Companies with better results have more comments concerning CSR and focus primarily on the environment and employees. Without regard to company results, the least attention is paid to the area of human rights, which is clearly linked to the fact that this issue is relatively extensively regulated by legislation, so activity in this area need not be emphasized.

For a comprehensive assessment of the relationship between informing stakeholders concerning CSR activities and the companies' financial outcomes, the Altman Z-score was used as an index of a company's credit strength. 
Evaluating text information in conjunction with the Altman Z-score showed that the companies evaluated as financially healthy - or at least located in the "gray zone" - using this cumulative method present more information on CSR activities in their annual reports. This corresponds to the analyses conducted and provides support for a positive relationship between CSR and corporate financial performance.

Communication about CSR activities was assessed only according to the companies' annual reports. Thus, the existence of other tools or sources of communication, e.g., company websites, newsletters, social media sites, etc., have not been precluded. External communication was given preference in this paper, though it cannot be assumed that all employees - as one of the groups of stakeholders - are interested in the information contained in the annual reports. Communication about CSR activities should be conducted not only externally, but also internally.

The strategic impact of CSR activities is also important. CSR should be understood as part of a corporate strategy because CSR supports the creation of productive relationships with stakeholders that represent different social and environmental needs. Therefore, all CSR activities need to be considered as significant long-term activities that need to be taken into account in business objectives and for which financial resources must be secured.

Our current research has focused on U.S. publicly-traded companies and uses data from annual reports for 2014. In recent years, there has been pressure on corporate social behavior and the development of CSR activities has intensified in the U.S., with the need for a sufficient presentation. Similarly, this is also the case in European countries, where separate reports focusing on the presentation of sustainable development and related CSR activities are gradually being developed. Currently, annual reports remains a key source of information about CSR implementation and its impact on business results. Economically, as a result of globalization, conditions are similar in America and Europe, so it can be assumed that the findings of this study can also be exploited in other countries.

\section{ACKNOWLEDGEMENT}

This work was supported by Grant No: GA16-19590S, a scientific research project of the Czech Science Foundation.

\section{REFERENCES}

Agan, Y., Kuzey, C., Acar, M. F., \& Aç1kgoz, A. (2016). The relationships between corporate social responsibility, environmental supplier development, and firm performance. J. Clean. Prod., 112, 1872-1881.

Archel, P., Husillos, J., \& Spence, C. (2011). The institutionalization of unaccountability: loading the dice of Corporate Social Responsibility discourse. Acc. Organ. Soc., 36(6), 327-343.

Bayaraa, B. (2017). Financial performance determinants of organizations: The case of Mongolian companies. Journal of Competitiveness, 9(3), 22-33. https://doi.org/10.7441/joc.2017.03.02

Becchetti, L., \& Ciciretti, R. (2009). Corporate social responsibility and stock market performance. Appl. Fin. Econ., 19(16), 1283-1293.

Blei, D. M., Ng, A. Y., \& Jordan, M. I. (2003). Latent dirichlet allocation. Journal of Machine Learning Research, 3(1), 9931022.

Brammer, S., Brooks, C., \& Pavelin, S. (2006). Corporate social performance and stock returns: UK evidence from disaggregate measures. Financial Management, 35(3), 97-116.

Cavaleri, S., \& Shabana, K. (2018). Rethinking sustainability strategies. Journal of Strategy and Management, 11(1), 2-17.

Contrafatto, M. (2014). The institutionalization of social and environmental reporting: an Italian narrative. Account. Organ. Soc., 39(6), 414-432. 
Cowen, S. S., Ferreri, L. B., \& Parker, L. D. (1987). The impact of corporate characteristics on social responsibility disclosure: a typology and frequency-based analysis. Acc. Organ. Soc., 12, 111-222.

Crisóstomo, V. L., Freire F. S., \& Vasconcellos F. C. (2011). Corporate social responsibility, firm value and financial performance in Brazil. Social Responsibility Journal, 7(2), 295-309.

Deloitte. (2018). Global Human Capital Trends 2018. Available at: https://www2.deloitte.com/au/en/pages/human-capital/articles/human-capital-trends.html.

DiSegni, D. M., Huly, M., \& Akron, S. (2015). Corporate social responsibility, environmental leadership and financial performance. Social Responsibility Journal, 11(1), 131-148.

Dobrovič, J., \& Timková, V. (2017). Examination of factors affecting the implementation of organizational changes. Journal of Competitiveness, 9(4), 5-17. doi:10.7441/joc.2017.04.01.

Engelberg J. E., Reed, A. V., \& Ringgenberg, M. C. (2012). How are shorts informed? Short sellers, news, and information processing. Journal of Financial Economics, 105, 260-278.

Engert, S., \& Baumgartner, R. J. (2015). Corporate sustainability strategy bridging the gap between formulation and implementation. Journal of Cleaner Production, 13, 822-834.

Flammer, C. (2014). Does the product market competition foster corporate social responsibility? Evidence from trade liberalization. Strategic Management Journal, 36(10), 1469-1485. doi:10.1002/smj.2307.

Forbes. (2018). Designing A Fairer, More Effective Job Application. Available at: https://www.forbes.com/sites/gradsoflife/2018/09/20/designing-a-fairer-more-effective-jobapplication/\#39d713432546

Friedman, M. (1970). The Social Responsibility of Business is to Increase its Profits. The New York Times Magazine. September 13, 1970. Available at: http://umich.edu/ thecore/doc/Friedman.pdf

Galbreath, J. (2006). Does primary stakeholder management positively affect the bottom line? Some evidence from Australia. Manag. Decis., 44(8), 1106-1121.

Hajek, P., \& Henriques, R. (2017). Mining corporate annual reports for intelligent detection of financial statement fraud - A comparative study of machine learning methods. Knowledge-Based Systems, 128, 139-152.

Hajek, P., Olej, V., \& Myskova, R. (2014). Forecasting corporate financial performance using sentiment in annual reports for stakeholders' decision-making. Technological and Economic Development of Economy, 20(4), 721-738.

Huffman, M. L. (2013). Organizations, managers, and wage inequality. Sex. Roles, 68(3-4), 216-222.

Javed, M., Rashid, M. A., \& Hussain, G. (2016). When does it pay to be good-A contingency perspective on corporate social and financial performance: would it work? Journal of Cleaner Production, 133, 1062-1073.

Kim, Y., Park, M. S., \& Wier, B. (2012). Is earnings quality associated with corporate social responsibility? Acc. Rev., 87(3), 761-796.

Kimmel, P. D., Weygandt, J. J., \& Kieso, D. E. (2013). Financial Accounting: Tools for Business Decision Making, $7^{\text {th }}$ ed., John Wiley \& Sons, NJ.

Komashie, D. (2014). Return on Equity. Available at: https://www.readyratios.com/reference/profitability/ return_on_equity.html?MID=1162\&\#message1162.

Labuschagne, C., \& Brent, A. C. (2008). An industry perspective of the completeness and relevance of a social assessment framework for project and technology management in the manufacturing sector. J. Clean. Prod., 16(3), 253-262.

Lagoarde-Segot, T., \& Paranque, B. (2018). Finance and Sustainability: From ideology to utopia. International Review of Financial Analysis, 55, 80-92.

Myskova, R., \& Hajek, P. (2016). The effect of managerial sentiment on Market-to-Book ratio. Transformation in Business \& Economics, 15(2A), 498-513.

Myskova, R., \& Hajek, P. (2017). Comprehensive assessment of firm financial performance using financial ratios and linguistic analysis of annual reports. Journal of International Studies, 10(4), 96-108.

Pencle, N. \& Mălăescu, I. (2016). What's in the words? Development and validation of a multidimensional dictionary for CSR and application using prospectuses. Journal of Emerging Technologies in Accounting, 13(2), 109-127.

Petrrík, T. (2005). Ekonomické a finanční ŕízení firmy. Czech Republic, Prague: Grada Publishing, 372 p.

Porter, M. E., \& Van der Linde, C. (1995). Green and competitive: ending the stalemate. Harv. Bus. Rev., 73(5), 120134. 
Piryani, R., Madhavi, D., \& Singh, V. K. (2017). Analytical mapping of opinion mining and sentiment analysis research during 2000-2015. Information Processing \& Management, 53(1), 122-150.

Rajnoha, R., \& Lesníková, P. (2016). Strategic performance management system and Corporate Sustainability Concept - Specific parametres in Slovak enterprises. Journal of Competitiveness, 8(3), 107-124. doi:10.7441/joc.2016.03.07.

Reverte, C., G_omez-Melero, E., \& Cegarra-Navarro, J. G. (2016). The influence of corporate social responsibility practices on organizational performance: evidence from Eco-Responsible Spanish firms. J. Clean. Prod., 112, 2870-2884.

Sarkis, J. (2009). A convincing industry that there is value in environmentally supply chains. Probl. Sustain. Dev., 4(1), 61-64.

Sedláček, J. (2011). Finančni analýza podniku. Czech Republic, Brno: BIZBOOKS, 160 p.

Seele, P., \& Gatti, L. (2015). Greenwashing revisited: in search of a typology and accusation-based definition incorporating legitimacy strategies. Business Strategy and the Environment, 26(2), 239-252. doi:10.1002/bse.1912.

Schreck, P. (2011). Reviewing the business case for corporate social responsibility: New evidence and analysis. Journal of Business Ethics, 103(2), 167-188. doi:10.1007/s10551-011-0867-0.

Simionescu, M. (2016). The competition between London companies regarding their financial performance. Journal of Competitiveness, 8(2), 5-16, doi:10.7441/joc.2016.02.01.

Surroca, J., Tribo, J. A., \& Waddock, S. (2010). Corporate responsibility and financial performance: The role of intangible resources. Strategic Management Journal, 31(5), 463-490.

Torugsa, N. A., \& O'Donohue, W. (2012). Capabilities, proactive CSR and financial performance in SMEs: empirical evidence from an Australian manufacturing industry sector. Journal of Business Ethics, 109, 483-50.

Turban, D. B., \& Greening, D. W. (1996). Corporate social performance and organizational attractiveness to prospective employees. Acad. Manag. J., 40, 658-672.

U. S. Census Bureau. (2015). Economic Census Data. Available at: http://www2.census.gov/econ/qfr/press/ qfr144mg.pdf.

U. S. Census Bureau. (2015). Economic Census Data. Available at: http://www2.census.gov/econ/qfr/pubs/ qfr14q4.pdf.

Van Marrewijk, M. (2003). Concepts and definitions of CSR and corporate sustainability: Between agency and communion. Journal of Business Ethics, 44(2-3), 95-105.

Wagner, M. (2010). Corporate social performance and innovation with high social benefits: a quantitative analysis. Journal of Business Ethics, 94(4), 581-594.

Weber, M. (2008). The business case for corporate social responsibility: A company-level measurement approach for CSR. European Management Journal, 26(4), 247-261.

Wolf, J. (2014). The relationship between sustainable supply chain management, stakeholder pressure, and corporate sustainability performance. Journal of Business Ethics, 119(3), 317-328. 